\title{
Membaca Repertoire Okky Madasari Dalam Novel Maryam: Kajian Respon Estetik Wolfgang Iser
}

\author{
Moch. Zainul Arifin \\ Pascasarjana Fakultas Ilmu Budaya, Universitas Gadjah Mada \\ mochzainul2018@mail.ugm.ac.id; arifin_zain90@yahoo.com
}

\begin{abstract}
This paper tried to trace Okky Madasari's repertoire in Maryam novel. Research analysis used Wolfgang Iser's aesthetic response in his book The Act of Reading: A Theory of Aesthetic response (1987). The results showed that the accumulation of Okky's interview as a journalist about Ahmadiyya in Lombok had presented the Ahmadiyya socio-cultural problems in Lombok, and the old literary texts as background. Okky used social norms in the form of conflict of expulsion and burning of Ahmadiyya, while historical norms appear from year to year tragedies are displayed from 1999 to 2003. Cultural norms of Ahmadiyya must be married to fellow Ahmadis, and Ahmadis have their own mosques for their worship activities. The old literature that influenced it seemed to be Ronggeng Dukuh Paruk, Pulang novel, and Saksi Mata as well as the story of Maryam binti Imran. All of these elements build the meaning of the novel by Okky as a strategy to slip hopes, views, and criticisms of background reality to convey foreground that is intended to be addressed. Foreground that appears is Okky trying to reflect at the same time the contemplation of the tragedy for the tragedy that befell the Ahmadis in Lombok. So that the hope that appears is to voice justice, human rights and civilization better. Because Indonesian constitution becomes and protects every citizen's rights.
\end{abstract}

Keywords: Repertoire, socio-cultural norms, history, old literature and foreground

\begin{abstract}
Abstrak: Tulisan ini berupaya menelusuri repertoire Okky Madasari dalam novel Maryam. Analisis penelitian menggunakan respon estetik Wolfgang Iser dalam bukunya The Act of Reading: A Theory of Aesthetic response (1987). Hasil penelitian menunjukkan bahwa akumulasi dari wawancara Okky sebagai wartawan tentang Ahmadiyah di Lombok telah menampilkan permasalahan sosio-budaya-sejarah Ahmadiyah di Lombok, dan teks-teks sastra lama sebagai background. Okky menggunakan norma sosial berupa konflik pengusiran dan pembakaran Ahmadiyah, sementara norma sejarah tampak dari tahun demi tahun tragedi yang ditampilkan dari tahun 1999 hingga 2003. Norma budaya berupa Ahmadiyah harus menikah dengan sesama pemeluk Ahmadi, dan Ahmadi memiliki masjid sendiri untuk kegiatan ibadah mereka. Sastra lama yang mempengaruhi tampaknya novel Ronggeng Dukuh Paruk, Pulang, dan Saksi Mata sekaligus ditambah kisah Maryam binti Imran. Semua unsur tersebut membangun makna novel yang oleh Okky dilakukan strategi untuk menyelipkan harapan, pandangan, dan kritikan terhadap realitas background untuk menyampaikan foreground yang hendak dituju. Foreground yang tampak
\end{abstract}


adalah Okky berupaya merefleksikan sekaligus kontemplasi dari tragedi demi tragedi yang menimpa Ahmadiyah di Lombok. Sehingga harapan yang tampak adalah menyuarakan keadilan, HAM, dan peradaban yang lebih baik lagi. Sebab konstitusi Indonesia menjadi dan melindungi setiap hak warga negara.

Kata kunci: Repertoire, norma sosial-budaya-sejarah, sastra lama dan foreground

\section{PENDAHULUAN}

Keberadaan karya sastra tidak dapat dilepaskan dari realitas kehidupan walupun seorang pengarang telah melakukan tendensi secara sadar dari kondisi sosial, historis dan budaya yang melingkunpinya. Dengan demikian, sastra sebagai fiksi memungkinkan adanya relasi fakta-fakta di dalamnya. Di antara karya sastra Indonesia yang menunjukkan adanya relasi antara fakta sosiologis, historis, dan budaya sebagai realitas di dunia nyata dengan fiksi sebagai dunia imajiner pengarang ialah novel Maryam karya Okky Madasari.

Novel Maryam karya Okky Madasari merupakan salah satu novel yang berbicara soal latar sejarah, budaya dan sosiologis terhadap kaum Ahmadiyah di Lombok pada tahun 2010. Novel-yang diterbitkan pada 2012-ini dilatarbelakangi oleh keinginan untuk mengamati wacana tekstual pengarang yang menyuarakan kaum tertindas sekaligus menjadi mediator yang menjembatani konflik antara Ahmadiyah dengan Islam fundamentalis atau sebut saja kelompok penentang. Dengan mengangkat sebagaian kecil kisah pilu warga Ahmadiyah yang memperjuangkan hak-haknya sebagai warga negara Indonesia, novel ini menampilkan bahwa hanya karena perbedaan pemahaman agama, mereka menjadi korban kekerasan dan diskriminasi.

Novel ini berkisah tentang seorang perempuan bernama Maryam yang lahir dan dibesarkan oleh orang tua yang adalah pengikut aliran Ahmadiyah. Hidup dalam posisi berbeda, marjinal, terpinggirkan dan terdiskriminasi dengan masyarakat pada umumnya membuat Maryam terusir dari rumah orang tua, rumah mertua, dan kampungnya juga lantaran iman seorang Ahmadiyah. Demikian juga yang kebanyakan terjadi saat kelompok Ahmadiyah diusir, dan dirusak rumah dan masjid mereka pada tahun 2010 di Lombok, Nusa Tenggara Barat.

Kehadiran unsur sosial, budaya, sejarah tadi juga tidak lepas dari unsur sastra sebelumnya. Sastra yang berbicara diskriminasi terhadap kelompok minoritas banyak hadir di kancah kesusasteraan Indonesia pada masa Orde Baru hingga Reformasi, sebut saja seperti novel Ronggeng Dukuh Paruk karya Ahmad Tohari pada tahun 1982, Cerpen Saksi Mata karya Seno Gumira Ajidarma 1992, novel Pulang karya Leila 
S. Chudori dan sebagainya. Maka tidak dapat dipungkiri bahwa keberadaan semua unsur tersebut ikut menginspirasi lahir-nya karya para pengarang Indonesia mutakhir, mulai dari pemakaian judul, nama tokoh, penokohan, hingga tema yang tercermin dalam karya sastranya.

Keadaan ini sebetulnya me-negaskan apa yang pernah diungkap oleh Teeuw (1983:11-12), bahwa penciptaan karya sastra Indonesia berada dalam ketegangan antara tradisi atau disebut konvensi dan pembaha-ruan atau inovasi. Keseluruhan unsur tersebut sebagai sumber inspirasi sastra kontemporer dalam membentuk nilai artistik dan estetiknya ketika dibaca. Pengarang mengolah semua unsur untuk menemukan keotentikan karyanya yang memotivasi munculnya inovasi kreatif dan menghadirkan karya sastra kontemporer yang penting serta memiliki kemandirian, (Sudibyo, 1993:1). Kebaruan ini dapat berupa mengurangi, menambahkan, bahkan mengubah cerita yang sudah ada, guna terciptanya sebuah cerita yang benar-benar baru, bukannya imitasi. Usaha tersebut memiliki tujuan-tujuan tertentu dari pengarang, salah satunya, fiksi digunakan untuk merespon fakta dalam kehidupan realitas.

Segala persoalan fakta dan fiksi dalam karya novel Maryam menjadi fokus kajian karena memiliki kecenderungan seperti yang sudah dipaparkan. Semua unsur diolahnya, sehingga terjadi peleburan antara realitas (fakta) dengan imajinasi (fiksi) yang kemudian menghasilkan sebuah karya fiksi yang difaktakan, fakta yang difiksikan. Penelitian novel dengan tujuan mengetahui teks-teks yang berbicara tentang sosial, budaya, sejarah, serta keseluruhan kultur yang melingkupi teks atau diluar teks novel diperlukan teori dan metode yang tepat. Teori respon estetik Wolfgang Iser yang terpapar dalam buku The Act of Reading: A Theory of Aesthetic Response (1987) dipilih sebagai pisau analisis untuk mengungkap repertoire berupa norma sosial, norma budaya, norma sejarah, keberfungsian karya sebelumnya, dan mengungkap apa yang hendak disampaikan Okky Madasari lewat novelnya Maryam tersebut.

Interaksi antara pembaca-peneliti dengan teks menghadirkan area indeterminasi (wilayah ketidak-pastian) atau tempat kosong (lesteleen) yang memungkinkan untuk dimaknai secara kreatif dan menyeluruh, namun tidak semena-mena. Pembaca implisit (impliedreader) dalam teks juga yang menawarkan efek, yang kemudian mengarahkan reaksireaksi pembaca untuk mendekatinya. Pembaca memi-liki strategi (tindakan-tindakan pemahaman) yang berfungsi mengarahkan perhatian pada teknik konkretisasiberdasarkan keterse-diaan memori dan cakrawala harapan yang dimiliki. Dari sana kemudian imajinasi 
pembaca dikehendaki dalam membaca karya sastra pengarang, atau pengarang menghendaki pembacanya melakukan sesuatu dalam membaca karya mereka (Junus, 1985, 46).

Penelitian ini membagi data menjadi dua, yaitu data primer berupa teks novel Maryam karya Okky Madasari (2012) sebagai objek material dan formal, dan data sekunder berupa sumber-sumber referensi tertulis (buku, jurnal, laporan penelitian) yang sesuai dengan teks kajian. Selain itu akan dilihat kemungkinan lain, keterkaitan antara realitas ekstratekstual yang menjadi latar belakang (background) untuk mewujudkan latar depan (foreground) karya berupa petunjuk kemungkinan hubungan dengan norma sosial, norma budaya, norma historis, dan teks-teks cerita rakyat yang dimunculkan dalam teks. Prosedur penelitian yang menghasilkan data deskriptif berupa kata-kata tertulis atau lisan dari orang-orang dan perilaku yang diamati merupakan metode kualitatif (Boglan dan Taylor dalam Moeloeng, 1989: 2-3).

\section{PEMBAHASAN}

Sebelum melangkah jauh menuju pembahasan, tampaknya narasi kunci dari novel Maryam karya Okky Madasari ini perlu diulas terlebih dahulu guna mendapatkan gambaran kronologis ceritanya. Novel Maryam ini menarasikan perjuangan seorang perem-puan, bernama Maryam, menjalani hidup di tengah diskriminasi masyarakat Indonesiala kemudian menjadi andalan keluarga dan kaumnya untuk memper-juangkan hak-hak dasar sebagai manusia, yaitu untuk dapat hidup aman, bebas dari tekanan, diskriminasi dan kekerasan. Terlahir sebagai se-orang Ahmadiyah yang selama ini dipandang sesat oleh masyarakat tidaklah mudah. Hidup yang penuh banyak kejadian tidak menyenangkan hingga segala bentuk penghinaan pernah ia rasakan. Maryam, menjalani hari-harinya dengan berat. Meskipun akhirnya ia berusaha tegar menghadapinya dan menerima dirinya sebagai seorang Ahmadi.

Beban kehidupan itu dimulai dari penghinaan masyarakat terhadap Fatimah, adik Maryam yang menerima perlakuan buruk dari dari pihak sekolahnya karena dianggap sebagai penganut aliran sesat. Hingga akhirnya Fatimah mendapatkan nilai merah pada mata pelajaran agama di rapornya, yang justru menjadi ironi karena Fatimah sendiri tergolong sebagai anak yang rajin dan pintar di sekolahnya.

Sedangkan, Maryam sendiri setelah tamat SMA, ia memutuskan untuk meninggalkan Lombok tempat keluarganya untuk meneruskan kuliah di Surabaya. Hubungan jarak jauh dengan keluarga tidaklah 
menjadi kendala bagi Maryam untuk menuntut ilmu, sebab di Surabaya ia tinggal bersama sanak keluarganya sesame Ahmadi. Dan hingga ia berkenalan dengan pemuda yang bernama Gamal pada suatu pengajian rutin yang diselenggarakan Ahmadiyah.

Kedekatan Maryam dengan Gamal rupanya telah sampai kepada keluarga Pak Khairudin ayah Maryam di Lombok, sehingga keluarga Maryam memustuskan menyetujui hubungan mereka karena sesame Ahmadi. Dan apabila tidak ada halangan pernikahan Maryam dan Gamal dilangsungkan setelah Maryam menamatkan kuliahnya. Namun, ternyata berkebalikan semua rencana. Gamal menjadi berubah sikapnya terhadap Maryam dan pada kelurganya yang Ahmadi, setelah ia kembali dari magang kuliahnya. Gamal mengatakan Ahmadi itu sesat, sehingga ia kemudian meninggalkan Maryam dan keluarganya. Hal terebut yang membuat Maryam sangat terpukul, sehingga ia memustukan untuk merantau ke Jakarta setelah ia menamatkan kuliah di Surabaya, dengan harapan ia dapat melupakan semua kenangan bersama Gamal.

Kemudian di Jakarta ia tidaklah sulit mencari pekerjaan karena Maryam memiliki kelebihan, dan ia bekerja di sebuah bank swasta di Jakarta. Hingga ia bertemu dengan Alamsyah. Hubungan Maryam dengan Alamsyah juga tidaklah mudah, karena Alamsyah tidaklah mendapat restu dari orang tua Maryam sebelum dirinya masuk Ahmadiyah. Hal tersebut yang ditentang Maryam, karena Maryam menganggap lebih baik Maryam mengikuti Alamsyah ketimbang Alamsyah yang harus mengikuti kehendak keluarga Maryam. Akhirnya pernikahan Maryam dengan Alamsyah dilangsungkan tanpa hadirnya pihak keluarga Maryam. Namun, pada awal pernikahan ada prosesi di mana Maryam dianggap sebagai penganut aliran sesat dan kemudian Maryam di sumpah untuk memeluk agama Islam sesuai keyakinan Alamsyah.

Tekad Maryam besar untuk melupakan masa lalu dirinya, namun pehak keluaraga dari Alamsyah selalu mengkaitkan Maryam sebagai mantan penganut aliran sesat, sehingga dosanya tak termaafkan akibatnya Maryam tidak juga diberikan keturunan dari Alamsyah. Polemik antara Maryam dan keluarga Alamsyah terjadi terus menerus, hingga akhirnya Maryam jengah dan memutuskan untuk bercerai dengan Alamsyah dan kembali lagi pada keluarganya di Lombok. Maryam tersadar hal itu dikarenakan ia tidak mendengarkan anjuran orang tua.

Keberadaan Maryam di Lombok, keadaannya telah berbeda di awal kepergiannya. Hal itu karena rumah Maryam yang semula berada di pantai Gerupuk telah berpindah di Gegurung, itu dikarenakan adanya 
penyerangan yang dilakukan oleh warga kepada rumah Maryam dan keluarga yang dianggap sesat. Terkejut Maryam mendapati keadaan seperti itu, karena toleransi antar sesame dahulu sangat erat hingga akhirnya ia memutuskan pergi semuanya berubah.

Hingga akhirnya Maryam dijodohkan dengan Umar, sesame anggota Ahmadi oleh Pak Khairudin. Tak lama kebahagiaan itu, kembali lagi rumah pengikut Ahmadiyah diserang lagi oleh warga yang tidak terima dengan keberadaan Ahmadiyah di kampungnya. Hal tersebut yang menyulut emosi Umar, Pak Khairudin, serta pemuda-pemuda Ahmadiyah yang lain. Karena Ahmadiyah menilai penyerangan dilakukan secara sepihak, tanpa adanya kompromi. Dan telah menyalahi HAM. Sehingga pertempuran terjadi, kemudian tak lama POLISI dating untuk menengahi dan mengungsikan semua anak-anak dan wanita ke gedung Transito, termasuk Maryam yang ketika itu sedang hamil.

Keadaan pengungsi Ahmadi di gedung Transito tidak kunjung membaik, karena keinginan mereka hanya ingin kembali menjalani kehidupan seperti biasa. Namun. Harapan itu pupus ketika POLISI setempat menjelaskan bahwa demi keamanan pengungsi Ahmadi tidak diperbolehkan kembali.

Pembelaan terhadap penderitaan kaum Ahmadi terus dilakukan hingga, perwakilan dari Ahmadi bertemu dengan Gubernur, namun mengejutkan pernyataan yang diterima. Bahwasannya Ahmadi dipersilahkan untuk menjauh dari Lombok untuk keamanan, pengungsi Ahmadiyah harus meminta perlindungan suaka dari Australia. Hingga anak pertama pasangan Maryam dan Umar terlahir, perjuangan keadilan terus dilakukan hingga akhirnya Maryam berinisiatif untuk menyurati Presiden demi meminta perlindungan dan keadilan.

Dari sinopsis tersebut, kemudian akan dianalisis berupa norma sosial-budaya-sejarah dan sastra lama yang mempengaruhi hadirnya novel Maryam ini. Kemudian akan ditelisik manifestasi foreground dari semua unsur tersebut.

\section{Norma dan Fakta Sosial-Budaya Masyarakat Lombok sebagai Repertoire}

Novel Maryam karya Okky Madasari menarasikan konflik dan pengusiran kaum Ahmadiyah yang terjadi di Lombok. Dari berbagai data dan informasi dikemukakan fakta bahwa kelompok Ahmadiyah masuk ke Indonesia pada tahun 1925. Ahmadiyah didirikan oleh Mirza Ghulam Ahmad (1835-1908) pada 1889 di satu desa kecil yang bernama Qadian, Punjab, India. Setelah Mirza Ghulam Ahmad meninggal, Ahmadiyah dipimpin Shadr Anjuman Ahmad. Kemudian diganti oleh putra pendiri 
Ahmadiyah yakni Mirza Bashiruddin Mahmud Ahmad. Pada masa kepemimpinan Bashiruddin ini para pengikut Ahmadiyah terbagi menjadi dua kelompok, yaitu Ahmadiyah Qadian dan Ahmadiyah Anjuman Isya'ati atau dikenal dengan Ahmadiyah Lahore. Pertama, kelompok Ahamdiyah Qadian, di Indonesia membentuk organisasi bernama Jemaat Ahmadiyah Indonesia yang telah berbadan hukum sejak 1952 (SK Menteri Kehakiman RI No. JA 5/23/13 Tgl. 13-3-1953). Kedua, kelompok Ahmadiyah Lahore, di Indonesia pengikut kelompok ini membentuk organisasi bernama Gerakan Ahmadi-yah Indonesia yang mendapat Badan Hukum No. XI Tgl. 30 April 1930.

Konflik antara kelompok Ahmadiyah dan kelompok penentang telah terjadi berkali-kali. Pengusiran dan penganiayaan dimulai pada tahun 1999. Kelompok penentang pun membakar masjid yang menjadi milik kaum Ahmadiyah di Bayan, Kabupaten Lombok Barat. Sebagian dari mereka terluka dan meninggal dunia akibat bacokan yang dilakukan oleh kelompok penentang. Ironisnya pemerintah Lombok Timur memberikan dua opsi; pertama, warga Ahmadiyah boleh tetap di Pancor tetapi keluar dari Ahmadiyah atau yang kedua, tetap berkeyakinan Ahmadiyah dan keluar dari Pancor.

Periode 90-an menjadi periode pesat perkembangan Ahmadiyah di Indonesia bersamaan dengan diluncurkannya Moslem Television Ahmadiyya (MTA). Ketika pengungsi Timor Timur yang membanjiri wilayah Indonesia setelah menduga adanya rumor bahwa Timor Timur ingin lepas dari Indonesia, hal ini memberikan kesempatan kepadsa Majelis Khuddamul Ahmasiyah Indonesia untuk mengirimkan tim Khidmat Khalq untuk berkhidmat secara terbuka. Tahun 2000, tibalah Hadhrat Mirza Tahir Ahmad ke Indonesia datang dari London menuju Indonesia. Ketika itu beliau sempat bertemu dan mendapat sambutan baik dari Presiden Republik Indonesia, K.H Abdurrahman Wahid dan ketua MPR Amin Rais.

Dalam novel Maryam juga diceritakan adanya konflik antara kelompok Ahmadiyah dan kelompok penentang yang disebabkan adanya kemarahan kelompok penentang terhadap kelompok Ahmadiyah. Mereka sangat tidak menyukai kehadiran kaum Ahmadiyah di wilayah mereka. Ketika salah seorang ustaz memmpin pengajian dengan berusaha, sebut saja, cenderung menghasut ummatnya untuk ikut terlibat mengusir keluarga Ahmadiyah. Mereka pun percaya sekali terhadap apa yang disampaikan sang ustaz dan ikut menolak dan mengusir kaum Ahmadiyah. Hal tersebut dapat dilihat dalam kutipan berikut, 
Saat menunggu Ustaz mulai memimpin pengajian, suara dari masjid jelas terdengar. Orang itu sedang bicara soal kelompok aliran sesat. Nama Ahmadiyah berkali-kali disebut. Semua yang ada di rumah Pak Khairuddin mulai tak tenang. Masing-masing berbicara dengan orang di sebelahnya. Berbisik-bisik, salingh bertanya. Raut muka penuh kemarahan, sekaligus rasa resah dan takut. Umar pun berbisik kepada bapak mertuanya. Bertanya itu suara siapa. "Tuan Guru Ahmad Rizki," jawab bapak Maryam. "Dua bulan ini sering sekali ada pengajian seperti itu. Tidak tahu apa maksudnya," lanjutnya tetap sambil berbisik (Madasari, 2012: 222).

"Usir orang Ahmadiyah dari Gegerung. Kalau masyarakat di sini tidak mampu mengusir, saya akan mendatangkan masyarakat dari tempat lain untuk mengusir mereka. . . darah Ahmadiyah itu halal!" (Madasari, 2012: 223).

Dari latar tempat, Novel Maryam ini menggunakan latar tempat di Lombok, Gerupuk, Gegerung, dan Gedung Transito. Lombok merupakan wilayah kampung halaman Maryam. Ia kembali ke Lombok untuk mencari kedua orangtuanya yang telah ia tinggali selama beberapa tahun lamanya hanya demi laki-laki yang ia cintai yang teryata hanya memberi harapan palsu. Beriku bukti kutipan yang terdapat dalam novel,

Hari itu juga Maryam meninggalkan daerah selatan. Menyusuri jalan raya menuju utara. Melewati pusat kecamatan Sengkol, tempat ia bersekolah SMP dan SMA, juga tempat bapaknya dulu tiap hari membawa keranjang-keranjang berisi ikan untuk dijual di pasar. Terus berjalan melalui kota-kota kecamatan lain: Panujak, Kediri, Cakranegara hingga Mataram, dari pusat Lombok itulah ia akan mencari di mana bapak, ibu, dan adiknya berada (Madasari, 2012: 60).

Latar tempat berikutnya berada di Gerupuk. Gerupuk adalah kampung kecil yang berada di pesisir selatan Lombok. Kampungnya para nelayan untuk mencari ikan di laut. Di tempat inilah, Maryam bersama orangtua dan adiknya tinggal sebelum ia diusir dari tempat itu. Berikut kutipan yang berada dalam novel,

Gerupuk hanyalah kampung kecil di sudut timur pesisir selatan Lombok. Nyaris tak dikenal. Peta-peta wisata menggambarkan hanya Kuta sebagai satu-satunya nama tempat di sepanjang garis pantai itu. Baru tahun-tahun belakang, ketika orang-orang asing 
mulai mengetahui ada ombak tinggi di kampung ini, Gerupuk mulai didatangi. Itu pun hanya oleh mereka yang ingin mencari kepuasan berdiri di papan selancar, menaklukkan ombak yang bergulang tinggi. Semuanya orang asing (Madasari, 2012: 41)

Pikiran Maryam langsung menerawang ke masa-masa ia masih tinggal di Gerupuk bersama keluarganya. Masa-masa jauh sebelum ia datang ke Jakarta, dan jauh sebelum keluarganya terusir dari rumah yang telah puluhan tahun mereka tinggali (Madasari, 2012: 169).

Dalam kejadian nyata sebagaimana yang dilansir oleh bbc.com (2013), sekitar 30 keluarga Ahmadiyah mengungsi dari desa mereka di Ketapang, Lombok Barat. Dengan demikian, Gerupuk yang direpresentasikan oleh Okky dalam novel Maryam sebenarnya di kejadian nyata adalah desa Ketapang di mana sebelumnya mengalami intimidasi dan kekerasan yang berujung pada pengusiran mereka.

Kemudian narasi dalam novel juga terjadi di lokasi Gegerung. Gegerung merupakan tempat keluarga Maryam tempati setelah diusir dari Gerupuk. Rumah yang ia dan keluarganya tempati di waktu itu. Gegerung inilah masih menjadi tempat tinggal jemaah Ahmadiyah yang pernah diusir. Hal ini juga terjadi dalam kejadian di mana Gegerung merupakan nama desa di kecamatan Lingsar, Lombok Barat. Maka dengan demikian nama gegerung ini memang benar adanya di realitas, tepatnya di Lombok, berikut kutipan dalam novel,

Meski terpisah dari rumah-rumah penduduk lain, tanah yang dihuni orang-orang Ahmadi itu termasuk kampung Gegerung. Sekitar satu setengah kilometer jauhnya dari perkam-pungan utama Gegerung, dipisahkan oleh sawah-sawah padi dan sungai (Madasari, 2012: 83).

Selanjutnya tentang Gedung Transito yang merupakan tempat keluarga Maryam mengungsi. Keluarga-nya diusir dari Gerupuk dan kini tinggal di Gedung Transito sebelum pindah ke Gegerung, di mana Pak Khairuddin beserta keluarga lainnya hidup dalam kesesakan. Tempat ini dipergunakan mereka sebagai tempat kegiatan agama mereka. Di mana mereka menjadikan tempat ini sebagai masjid tempat mereka beribadah. Berikut kutipannya,

Gedung Transito sekarang juga menjadi pusat kegiatan keagamaan mereka. Menggantikan masjid organisasi yang sampai kini tak bisa digunakan. Di sini setiap Jum'at orang-orang Ahmadi salat bersama. Seming-gu sekali ada pengajian, yang juga diikuti 
orang-orang Ahmadi dari daerah lain. Anak-anak kecil belajar mengaji bersama setiap sore. Diajar seorang ustaz yang baru datang dari Jawa. Ditugaskan organisasi untuk memberikan bimbingan khusus di gedung Transito (Madasari, 2012: 252).

Menurut yang dilansir oleh bbc.com (2013), tempat pengungsian yang ditinggal oleh sekitar 30 kelurga Ahamadiyah yang diusir dari desa Ketapang adalah Wisma Transito, Mataram, Nusa Tenggara Barat. Dengan demikian, Okky menuliskan narasi dengan pengungsian di gedung Transito menunjukkan bahwa Okky benar-benar mengambil nama dari wisma tersebut sebagai inspirasi hanya diganti wisma menjadi gedung.

Dalam novel Maryam, terdapat kebiasaan masyarakat yang tinggal di kampung Gerupuk. Keindahan kampung Gerupuk merupakan kampung kecil di timur pesisir pantai selatan Lombok. Gerupuk adalah tanah yang berdebu saat cuasa panas dan becek penuh kubangan selepas hujan juga deretan peragu-perahu nelayan, bau amis ikan, dan nelayan-nelayan berkulit legam menjadi kebiasaan hidup mereka dengan mendapatkan ikan, udang, teripang dan lain-lain. Berikut kutipan,

Tak ada keistimewaan lain yang ditawarkan Gerupuk selain ombak tinggi itu. Ia tak punya pantai indah berpasir putih, sebagaimana pantai-pantai lain yang berjajar di pesisir ini. Gerupuk adalah deretan perahu-perahu nelayan, bau amis ikan, dan nelayan-nelayan berkulit legam. Setiap orang hidup dari tingkatan ikan, udang, atau teripang (Madasari, 2012: 41).

Terdapat latar sosial dari segi tradisi yang membedakan antara Ahmadiyah dan penentangnya. Di mana kegiatan organisasi Ahmadiyah dan kelompok penetang berbeda. Kelompok Ahmadi juga memiliki masjid sendiri. Mereka tidak beribadah dengan muslim lainnya. Hal ini sebagaimana dalam kesaksian dari sebuah wawancara yang dilansir oleh bbc.com (2018) menyatakan bahwa pasca-fatwa MUI (Majelis Ulama Indonesia) terhadap Ahamdiyah, banyak masyarakat Ahmadi yang beribadah di masjid masyarakat sekitar justru kaum Ahmadi dilempar ke dalam kolam dan sajadah yang dipakai sholat dibakar karena tidak bisa disucikan lagi, lebih najis daripada anjing. Berikut kutipan wawancara yang dilansir bbc.com,

"Kami yang di Lombok ini tidak eksklusif tapi dieksklusifkan," tuturnya. 
Syahidin menambahkan pada awalnya mereka hidup berbaur dengan warga lain sampai terjadi sejumlah peristiwa yang menimpa orang-orang Ahmadiyah. Ia sendiri asli Lombok, suku Sasak.

"Dulu ada seorang Ahmadi di Pancor (Lombok Timur) salat bersama di masjid, orangnya diangkat dan diceburkan ke kolam. Terus tikar yang digunakan salat oleh orang Ahmadi katanya sudah tidak bisa dicuci lagi, lebih najis daripada anjing,"

Hal tersebut selaras dengan yang dihadirkan oleh Okky Madasari di dalam novelnya Maryam. Dengan menarasikan bahwa Pak Khairuddin dan beserta kaum Ahmadi lainnya memiliki masjid sendiri dan pengajian sendiri yang berbeda dengan yang dilakukan muslim lainnya. Bahkan Pak Khairuddin mendirikan salat Jum'at di masjid mereka, tidak ikut bergabung di masjid masyarakat umum. Berikut kutipan dalam novel,

Mereka semua juga tahu, Pak Khairuddin punya kelompok pengajian sendiri. Beberapa kali ada pengajian di rumah Pak Khairuddin, didatangi oleh orang-orang jauh. Mereka semua juga sudah paham, keluarga Pak Khairuddin punya musala kecil di belakang rumah. Pada hari jum'at, menjelang zuhur, Pak Khairuddin pergi dengan sepeda motornya, salat Jum'at entah di mana. Semua tahu mereka berbeda. Tapi mereka juga sadar mereka punya satu nama agama. Maka biasa saja ketika satu-dua kali dalam obrolan ada yang berkata, "Itu beda, itu Islamnya Pak Khairuddin," atau, "Itu masjid kelompoknya Pak Khairuddin" (Madasari, 2012: 56).

Kelompok penetang yang ingin merusak kelompok Ahmadiyah semula hidup rukun sebagai tetangga dengan Pak Khairuddin dan Jemaah Ahmadiyah lainnya. Kemudian semua berubah ketika ada pendapat yang menyatakan bahwa Ahmadiyah telah menduakan nabi dan itu tidak bisa ditolerir lagi. Maka kehidupan yang mulanya damai dan tentram kini mereka selalu gelisah dan tidak mampu berdiam diri kembali, berikut kutipannya,

Orang-orang yang mereka anggap telah menduakan nabi mereka dan telah memperlakukan agama sesuai keinginan mereka. Bukan lagi berdasar yang seharusnya (Madasari, 2012: 51).

Mereka marah pada orang-orang yang selama puluhan tahun hidup rukun sebagai tetangga. Mereka melempar batu ke 
genteng, memecahkan kaca jendela, merusak pagar dengan parang dan cangkul. Laki-laki dewasa semuanya siaga. Mengepung rumah orang-orang yang mereka anggap telah menyimpang (Madasari, 2012: 51).

Hal ini sebagaimana pengakuan Tuan Guru Bajang Zainul Majdi selaku Gubernur NTB yang diwawancara oleh Tirto.com bahwa sebenarnya dahulu masyarakat Ahmdiyah dan masyarakat sekitar hukum rukun dan damai. Tetapi hal itu berubah setelah ada provokasi yang menjadi pemicu penganiayan, pembakaran hingga pengusiran kaum Ahmadiyah dari daerah mereka. Berikut kutipan singkat pernyataan TGB Zainul Majdi,

"Mereka, kan, sebetulmnya selama ini sudah hidup damai, lalu kok tiba-tiba terprovokasi seperti itu, kan, pasti ada pemicunya. Kalau dilihat pemicu sementara masih sangat sepele. Saya masih meragukan. Makanya saya minta untuk dicek oleh Bina Daerah di sini dan teman-teman kepolisian," kata TGB kepada Tirto, pada minggu.

Hal ini juga digambarkan pada perbedaan antara maryam dengan tuan Guru Ahmad Rizki yang disebabkan karena Tuan Guru Ahmda Rizki sebagai penghasut warga Gerupuk dengan memerintahkan orang-orang ikut mnelakukan penyerangan bersamaan terhadap Maryam. Hal itu dilakukan dengan menyatakan bahwa Gegerung tidak pantas menjadi tempat bagi orang-orang Ahmadiyah untuk melakukan kegiatan. Hal tersebut tampak dalam kutipan berikut,

Di dalam berita tertulis Tuan Guru Ahmad Rizki yang memerintahkan penyerangan itu. Sebagaimana yang telah Maryam dengar sendiri lewat suara keras dari masjid. Seperti orang yang ditontonnya di televisi beberapa waktu lalu, Tuan Guru Ahmad Rizki juga menyebut fatwa sesat sebagai alasan ia memerintahkan penyerangan (Madasari, 2012: 233).

\section{Norma dan Fakta Sejarah dalam novel Maryam karya Okky Madasari}

Novel Maryam karya Okky Madasari mengajak pembaca untuk menemukan dan melihat kenbali konflik perdarah, pengusiran dan penderitaan kaum Ahmadiyah di Lombok. Latar penceritaan kerusuhan berkisar antara tahun 1999-2003. Berikut akan diulas lebih detail tentang fakta sejarah dari tahun 1999, 2001 dan 2003 yang dialami oleh kaum Ahmadi yang sebenarnya di Lombok. Kemudian akan 
direlevansikan dengan kejadian sesuai tahun masing-masing yang berada di dalam novel Maryam.

\section{- Tahun 1999}

Dalam fakta sejarah, peristiwa penolakan dan kerusuhan antara Jemaat Ahmadiyah dan kelompok penengtang di Lombok pertama kali terjadi pada tahun 1999. Hal ini dapat diketahui dari sebuah interview Syadihin, salah seorang Jemaat Ahmadiyah yang pernah merasakan pengalaman pilu kerusuhan dan pembakaran masjid mereka yang dilansir oleh rappler.com saat mengun-jungi pengungsi jemaat Ahmadiyah di Lombok.

"Kami diusir dari rumah oleh saudara sesama muslim sendiri yang terprovokasi. Padahal, sebelum itu tidak terjadi apa-apa. Kami hidup damai berdampingan, sampai akhirnya terjadi peristiwa itu," kata Syahidin.

Syahidin adalah salah seorang pengungsi dari Jemaat Ahmadiyah yang mengalami secara langsung peristiwa kerusuhan dan penganiayaan pada tahun 1999 di mana saat itu masjid milik kaum Ahmadiyah di Bayan, kabupaten Lombok Barat, dibakar dan sebagian dari mereka terluka dan satu orang meninggal akibat bacokan. Dan para kaum penentang memaksa kaum Ahmadiyah agar keluar dari keyakinan mereka.

Dan di dalam novel Maryam memang benar dituliskan juga bahwa peristiwa kerusuhan jemaat Ahmadiyah pertama kalinya terjadi. Hal tersebut seperti dalam kutipan berikut,

Memang pernah sekali terjadi ribut-ribut, tambah Zulkhair. Tapi itu dulu sekali. "Semua orang sudah memaklumi. Pasti saat itu karena negara kita sedang kacau. Ribut di mana-mana." Zulkhair menyebut peristiwa itu terjadi pada tahun 1999. Tak lama setelah televisi menayangkan peristiwa kerusuhan di Jakarta dan di banyak kota. Seorang Ahmadi dibunuh di daerah utara. Seorang lagi luka parah (Madasari, 2012: 69).

\section{- Tahun 2001}

Pada tahun 2001 di dalam novel adalah tahun terjadinya pengusiran terhadap Pak Khairuddin beserta keluarganya. Kejadian kerusuhan pada tahun 2001 yang benar-benar terjadi di Lombok adalah tepatnya di daerah dusun Sambi Elen, desa Loloan, Kecamatan Bayan, Lombok Barat sebagaimana yang dilansir dari beritagar.id (2018). Hal 
tersebut juga dimunculkan oleh Okky Madasari di dalam novelnya, berikut kutipannya,

Zulkhair mengawali ceritanya dari kedatangan Khairuddin dan keluarganya menjelang magrib, pada suatu hari di pertengahan tahun 2001. Zulkhair lupa tanggal dan bulan pastinya. Tapi katanya semua ada di catatan organisasi. Akan diambilkan kalau Maryam memang mau tahu. Maryam menggeleng katanya tidak perlu. Tanggal kejadian itu tidak terlalu penting baginya dibandingkan dengan kejadian itu sendiri. Maka Zulkhair pun melanjutkan ceritanya (Madasari, 2012: 68).

- Tahun 2003

Keluarga Pak Khairuddin pindah dari pengungsian dengan berusaha mencari rumah agar bisa tinggal, dan mencari penghasilan demi keluarga. Kejadian dalam novel dijelaskan pada tahun 2003. Sebagaimana yang dilansir oleh nasional.tempo.co (2003), kejadian perpindahan dari tempat pengungsian ke gedung Sasana Dharma Bakti. Hal tersebut juga terdapat di dalam novel, berikut kutipannya,

Pada awal tahun 2003, kata Zulkhair, keluarga Maryam pindah dari pengungsian. Pikapnya dijual. Sebagian hasil penjualan digunakan untuk mengontrak rumah. Sisanya untuk terus mempertahankan hidup, sambil mencari-cari cara untuk bisa punya penghasilan. Sebuah rumah kecil tak jauh dari tempat Zulkhair, di gang kecil di pinggiran. Mataram, menjadi tempat tinggal keluarga Maryam (Madasari, 2012: 78).

\section{Fungsi Sastra Lama dalam novel Maryam karya Okky Madasari}

Cerita tentang konflik, kekera-san, pembunuhan dan pengusiran akibat dari perbedaan iman telah diceritakan sebelumnya. Dalam novel Ronggeng Dukuh Paruk karya Ahmad Tohari pada tahun 1982, diceritakan soal masyarakat dukuh paruk yang mengalami pembantaian karena dianggap sebagai simpatisan PKI yang sebetulnya tidak mengerti apa-apa tentang karut marut perpolitikan negara. Tragedi berdarah G30s menjadi latar sejarah dari novel ini yang melihat dari sudut yang lebih spesifik yakni masyarakat dukuh paruk. Novel ini merepresentasikan tokoh sejoli bernama Srintil dan Ruas yang akhirnya Raus menjadi tentara dan Srintil menjadi korban pembantaian bersama warga dukuh paruk lainnya.

Dalam novel Maryam, tokoh Maryam menjadi representasi kaum Ahmadiyah dan Alam juga kekasihnya juga dapat merepresentasikan 
kelompok penentang Ahmadiyah. Dari sana sebelumnya kisah dari novel Maryam ini juga mengangkat isu diskriminasi minoritas, sebagaimana dengan warga dukuh paruk yang dianggap simpatisan PKI. Keduanya juga berangkat dari akar sejarah yang kuat. Apalagi juga bersinggungan dengan persoalan agama, di mana Ahmadiyah yang dianggap berbeda dan tidak diterima oleh kaum muslim Internasional, sementara PKI yang diasosiasikan ajaran Marxis yang ditafsirkan tidak mempercayai agama dan atheis.

Permasalahan diskriminasi Ekspol (tahanan politik) PKI dan keluarganya juga ditampilkan pada novel Pulang karya Leila S. Chudori. Novel ini bercerita soal penderitaan keluarga Ekspol Orde Baru yang berada di luar negeri, sekaligus stateless dan tidak bisa kembali ke tanah air tercinta, Indonesia. Pengusiran ekspol dan keluarganya ini menggambarkan hal yang sama dengan Maryam dan keluarganya yang terpaksa diusir dari rumah dan tanah kelahirannya. Penderitaan selama menjadi pengungsi di gedung Transito karena tidak memiliki pekerjaan dan tidak begitu mengenal keadaan sekitar.

Saksi Mata karya Seno Gumira Ajidarma tahun 1992 juga menampilkan penindasan pihak dominan yakni penguasa terhadap masyarakat Dili Timor Timur. Tragedi berdarah Dili menjadi inspirasi Seno dalam menuliskan kritik terhadap rezim orde baru dalam bentuk cerpen Saksi Mata. Di sini tampak bahwa Seno yang awalnya seorang jurnalis harus dipecat karena melaporkan kejadian berdarah Dili lalu menggunakan medium sastra untuk menyuarakan kengerian kejadian tersebut. Hal yang sama juga Okky dulunya seorang jurnalis kemudian menulis novel Maryam untuk menggambarkan betapa tersiksanya para penganut Ahmadiyah di Lombok.

Sastra lebih dulu yang mengangkat perjuangan seorang perempuan dalam perbedaan yang dimilikinyua juga tampak pada novel Ayah, Mengapa Aku berbeda? Karya Agnes Danovar. Angel yang seorang tunarungu tidak pernah menyerah untuk membuktikan bahwa ia terlahir ke dunia ini dengan tujuan yang diberikan tuhan. Ia berjuang meraih impiannya untuk membahagiakan ayahnya, setelah ibunya meninggal saat melahirkan dirinya. Banyak penderitaan yang dialami Angel karena perbedaannya, seperti awalnya ditolak masuk sekolah yang akhirnya juga menerimanya, kemudian dianggap cacat dan lemah oleh teman-teman sekolah, ditolak masuk kelompok tim musik, dst. Dari sana dalam novel Maryam juga menampilkan sosok Maryam yang harus menelan pil pahit berulang kali karena perbedaan keyakinan keluarganya. Maryam sering diejek teman di sekolah, kisah cintanya 
terpaksa kandas, pengusiran dan pengkucilan warga, penganiayaan dan sebagainya.

Novel Maryam juga mem-bangun lebih dari satu cerita dalam membangun makna novelnya. Pertama soal kisah Maryam sebenarnya sangat populer di dunia Islam bahkan juga di agama Kristen, yakni kisah seorang perempuan sholehah bernama Maryam binti Imran yang difirnah, dihina dan diusir dari tempat kelahirannya karena dianggap kotor telah hamil di luar pernikahan yang sah. Maryam mengandung seorang putra yang kelak diberi nama Isa. Anak inilah yang akan menjadi saksi kesucian sang ibu kepada kaumnya. Bayangkan Isa yang masih bayi dapat berbicara dengan lancar untuk membela sang ibu yang telah diusir, dihina dan dikucilkan oleh masyarakat. Hal ini juga terepresentasikan dalam novel Okky Madasari. Dengan demikian, pemakaian nama tokoh 'Maryam' sebenarnya terinspirasi dari kisah Maryam binti Imran, seorang perempuan suci yang dihina dan diusir oleh masyarakat. Untuk itu, Maryam di dalam novel yang merepresentasikan kaum Ahmadi juga dianggap memiliki kesamaan nasib yakni diusir dan dikucilkan oleh masyarakat sesama muslim.

Yang kedua soal diskriminasi masyarakat Ahmadiyah di Lombok yang berujung pada penganiayaan dan pengusiran. Diskriminasi terhadap kaum minoritas banyak disinggung oleh karya sastra sebelumnya, seperti novel Ronggeng Dukuh Paruk, Saksi Mata, Pulang dst yang kesemuanya menyuarakan keadilan dan hak asasi manusia. Dengan demikian dapat dikatakan bahwa novel Maryam ini juga hendak menyuarakan keadilan, hak asasi manusia yang tercerabut dari kaum minoritas Ahmadi dan tuntutan terhadap peradaban yang lebih baik.

\section{Manifestasi Foreground dalam Maryam}

Pengusiran menjadi salah satu fokus yang disiratkan Okky Madasari dalam novel Maryam, suatu keadaan di mana awalnya dipicu oleh provokasi dari kelompok penentang yang akhirnya meluas dan mengakibatkan bahwa pihak yang menolak kehadiran Ahmadiyah di daerah mereka. Pengusiran bahkan hingga pembakaran tempat ibadah kaum Ahmadiyah ini dimunculkan karena suatu sebab yanhg dapat dikatakan politik identitas. Di dalam masyarakat multikultur seperti Indonesia tampaknya cukup menggelikan apabila politik identitas masih digaungkan bahkan oleh pihak mayoritas. Padahal sebenarnya politik identitas di luar negeri hanya disuarakan oleh mereka yang minoritas untuk menyuarakan hak mereka supaya keadilan dipenuhi melalui tuntutan setiap pengalaman warga negara di sanalah demokrasi diuji. Dengan berkembangkan politik identitas oleh pihak mayoritas, maka 
suara minoritas justru semakin tertekan. Hal ini lah yang tampak dari kaum Ahmadiyah yang suara mereka dibungkam oleh kelompok penentang.

Tuntutan terseirat novel Maryam ini sebenarnya tentang kedamaian dan kehangatan warga negara. Mengedepan-kan agama sebagai pembeda tentu bukan hal tersebut yang hendak diselengarakan dalam demokrasi, me-lainkan dalam aturan equality befor the law (warga negara setara di depan hukum). Dengan demikian tuntutan kepada peradaban untuk mengerti bahwa kemanusiaan lebih penting daripada obsesi politik identitas yang dipaksakan kepada warga negara yang lain. Banyak pengakuan dari korban Ahmadiyah yang berada di pengungsian Wisma Transito. Mereka tidak dapat bebas seperti dahulu. Mereka harus membangun keluarga, hidup, perekono-mian dan adaptasi lingkungan dari awal kembali. Suasana mencekam yang dialami ketiak pengusiran dan pem-bakaran hingga ada yanhg terbunuh adalah pengalaman pahit yang coba diucapkan oleh novel Maryam ini, sebagaimana dalam surat Maryam di akhir novel ini,

Kami hanya ingin pulang. Ke rumah kami sendiri. Rumah yang kami beli dengan uang kami sendiri. Rumah yang berhasil kami miliki lagi dengan susah payah, setelah dulu pernah diusir dari kampung-kampung kami.

Kami mohon keadilan. Sampai kapan lagi kami harus menung-gu (Madasari, 2012: 273-275).

Keadilan. Itulah yang berupaya disuarakan dengan novel Maryam ini. Tindakan diskriminasi, pengusiran dan pencekalan masyarakat Ahmadiyah sebenarnya seharusnya tidak ada lagi dalam masyarakat demokratis. Sebab setiap warga negara hanya dikenali oleh konstitusi yang mengatur negara, bukan oleh obsesi bengis ideologi yang menghalalkan darah manusia sebangsa, dan se-tanah air sendiri. HAM (Hak Asasi Manusia) yang menjadi basis dari konstitusi negara Indonesia seharusnya menjadi pedoman bagi setiap warga negara untuk menghormati setiap bentuk keyakinan warga negara. Bukan berarti harus percaya pada dan mengikuti ajaran Ahmadiyah, melain-kan kosntitusi melindungi haknya untuk berkeyakinan sesuai dengan keinginannya.

Akhirmya, kehadiran semua hal tersebut dalam novel Maryam merupa-kan aktualisasi dari norma-norma sosio-budaya-sejarah dalam masyarakat Ahmadiyah di Lombok. Hal tersebut yang menjadi menarik untuk ditelisik lebih jauh. Melalui penggambaran serta penokohan yang dikonstruksi sedemiki-an rupa dengan simbol Maryam binti Imran, 
perempuan suci yang diusir dan dikucilkan kaumnya, pengarangdalam hal ini Okky Madasari-dengan piawai menyuarakan apa yang menjadi basis filosofis dari konstitusi setiap negara yakni Kebebasan. Setiap warga negara berhak atas pendapat, berkeya-kinan, berkomunitas dan seterusnya yang kini dibungkam oleh paksaan obsesi fundamental. Melalui semua tokoh di dalam novel Maryam, Okky tampak memberikan dukungannya pada kelompok Ahmadiyah untuk mendapat-kan hak mereka kembali. Mendukung bukan berarti bagian dari Ahmadiyah, tetapi menyuarakan kemanusiaan dan keadilan yang dirampas secara paksa dari mereka. Dengan latar tempat, kejadian dan tahun kejadian, novel ini benar-benar seperti memotret kembali tragedi demi tragedi yang dialami oleh kaum Ahmadiyah di Lombok. Dan ini membuktikan bahwa novel Maryam karya Okky Madasari ini menarasikan sebuah cerita yang berlandaskan pada fakta yang sebenarnya. Namun demikian, fakta dan fiksi yang dihadirkan bukanlah fakta dan fiksi seutuhnya, melainkan sudah difiksikan.

Foreground yang ditampilkan Okky Madasari membentuk struktur organisasional makna yang telah secara optimal diperoleh melalui pembacaan teks. Repertoire yang ada telah meng-organisasikan reaksi-reaksi peneliti terhadap teks dan masalah-masalah yang dibawa Okky untuk pembaca-peneliti. Ungkapan secara optimal telah direlevansikan pada level kesadaran pembaca-peneliti. Hal tersebut juga telah disesuaikan pada keinginan dalam membuka diri terhadap satu pengalaman yang tidak familiar. Optimalisasi yang ada dalam pembahasan telah disesuai-kan pada strategi-strategi teks yang diaktualisasikan. Garis strategi tersebut dilakukan penyesuaian pada kerangka teori repertoire yang dikemukakan oleh Iser dalam buku The Act of Reading: A Theory of Aesthetic Response.

\section{PENUTUP}

Berdasarkan analisis di atas maka hasil penelitian menunjukkan bahwa dalam novel Maryam karya Okky Madasari menggunakan norma sosial-budaya-sejarah pengusiran Ah-madiyah di Lombok sebagai repertoire. Norma sosial yang tertangkap berupa konflik pengusiran, penganiayaan, pem-bakaran bahkan hingga pembunuhan kaum Ahmadiyah di Lombok. Norma budaya yang terdapat dalam novel adalah Ahmadiyah memiliki masjid yang digunakan untuk pengajian, salat Jum'at dan kegiatan Ahamdiah lainnya yang kemudian dibakar oleh kaum penentang. Ditambah lagi, peraturan adat Ahmadiyah harus menikah dengan sesama kaum Ahmadiyah sebab Ahmadiyah tidak diterima dan dipan-dang buruk oleh masyarakat lainnya. Lalu norma 
sejarah yang digunakan sebagai repertoire berupa sejarah dari tahun ke tahun, lebih tepatnya 1999 hingga 2003 tentang penganiayaan, pengusiran dan pembakaran yang dilakukan oleh kaum penentang Ahma-diyah. Tempat di mana kaum Ahmadiyah tinggal saat pengungsian, yakni gedung Transito kemudian desa kaum Ahmadiyah desa Gegerung dan Gerupuk benar-benar ditampilkan oleh pengarang sebagaimana yang terjadi pada fakta sejarah kaum Ahmadiyah di Lombok.

Kesemua norma yang mem-bangun makna novel tidak lepas dari peranan beberapa sastra terdahulu yang juga menceritakan diskriminasi terha-dap kaum minoritas, seperti novel Ronggeng Dukuh Paruk, Pulang, Saksi Mata dan seterusnya. Ditambah lagi bangunan makna juga didapat dari kisah Maryam binti Imran, seorang perem-puan suci yang dikucilkan dan diusir oleh kaumnya karena dianggap kotor hamil di luar pernikahan yang sah. Tetapi pada akhirnya semua percaya dengan kesaksian bayi Isa yang berbicara soal kesucian Maryam.

Novel Maryam ini merupakan refleksi yang ditangkap pengarang dalam konflik pengusiran dan penderi-taan kaum Ahmadiyah di Lombok. Permasalahan tersebut tampaknya ber-orientasi pada asas equality before the law (kesetaraan di depan hukum) setiap warga negara Indonesia dan tuntutan HAM yang dilukai oleh tragedi yang menimpa kaum Ahmadiyah pada tahun 1999 hingga 2003 di Lombok, Nusa Tenggara Barat. Kesimpulan ini didasarkan pada pelacakan ekuivalensi repertoire novel Maryam dengan norma sosial historis dan budaya serta teks-teks sastra lama yang digunakan pengarang. Okky Madasari tampaknya menekankan bahwa lahirnya politik identitas dan sikap peradaban yang belum matang terhadap perbedaan menjadi alasan akan lahirnya konflik identitas Ahmadiyah di Lombok. Okky tampaknya dengan menghadirkan novel Maryam merasa sangat penting menyuarakan keadilan, HAM dan peradaban yang lebih baik. Perbedaan keyakinan bukanlah alasan untuk menghalalkan darah warga negara bangsa sendiri untuk dianiaya, dikucil-kan bahkan dibunuh. Bukan berarti mendukung dan menjadi kaum Ahmadiyah, melainkan menyuarakan hak mereka yang dibungkam oleh kelompok mayoritas lain sehingga seharusnya nafas segar konstitusi dapat dihirup oleh setiap warga negara.

Melalui semua unsur tersebut, Okky melakukan pengkongkritan makna ekstratekstual menjadi makna tekstual dengan penambahan olahan bumbu estetis. Okky secara implisit menyodorkan harapan, pandangan, dan kritikannya atas fakta diskriminasi HAM pada kaum Ahmadiyah melalui latar belakang (background) untuk menghadirkan 
latar depan (foreground) yang hendak dituju. Okky memanfaatkan repertoire (gudang pengetahuan)nya untuk merespon realitas yang dilihat, diteliti, dibaca dan dirasakan dalam konflik pengusiran dan penganiayaan Ahmadiyah di Lombok, Nusa Tenggara Barat. Hasil dari penelusuran ini, penelitan tidak diarahkan pada makna statis dan absolut, melainkan makna yang terus bergerak sesuai harapan masingmasing pembaca-peneliti. Dengan demikian ilmu pengetahuan akan terus bergulir sebagaimana proses pembacaan masing-masing pada masa dan realitas sosial budaya yang berbeda, maka bukan tidak mungkin akan ditemukan makn-makna lain oleh pembaca-peneliti yang berbeda suatu hari nanti.

\section{DAFTAR PUSTAKA}

Ajidarma, Seno Gumira. 1994. Saksi Mata. Yogyakarta: Bentang Budaya. Chudori, Leila S. 2013. Pulang. Jakarta: Gramedia Pustaka Utama. Junus, Umar. 1985. Resepsi Sastra: Sebuah Pengantar. Jakarta: Gramedia Pustaka Utama.

Iser, Wolfgang. 1987. The Act of Reading: A Theory of Aesthetic Response. London: Johns Hopkins University Press.

Madasari, Okky. 2012. Maryam. Jakarta: Gramedia Pustaka Utama. Moeloeng, A. L.J. 1989. Metode Penelitian Kualitatif. Bandung: Remaja Rosdakarya.

Nurgiyantoro, Burhan. 1995. Teori Pengkajian Fiksi. Yogyakarta: Gadjah Mada University Press.

Sudibyo. 1993. Hubungan Intertekstual Novel Durga Umayi dengan Cerita

Tentang Durga. Yogyakarta: Fakultas Gadjah Mada.

Teeuw, A. 1984. Sastra dan Ilmu Sastra: Pengantar Teori Sastra.

Bandung: Firma Ekonomi. Tohari, Ahmad. 1982. Ronggeng Dukuh

Paruk. Jakarta: Gramedia Pustaka Utama.

http://duniabaca.com/asal-usul-sejarah-ahmadiyah-di-indonesia.html http://www.andreasharsono.net/2010/02/ahmadiyah-rechtstaat-danhakasasi 18.html

https://www.bbc.com/indonesia/berita_indonesia/2013/08/130802_a hmadiyah_lombok

https://beritagar.id/artikel/laporan-khas/kekerasan-berulang-

terhadap-jemaah-ahmadiyah-di-lombok

https://www.bbc.com/indonesia/dunia-42791329

https://tirto.id/kronologi-penyerangan-jemaat-ahmadiyah-di-lomboktimur-ntb-cKQY 